\title{
Chronic testosterone treatment induces selective insulin resistance in subcutaneous adipocytes of women
}

\author{
A Corbould \\ Prince Henry's Institute of Medical Research, Monash Medical Centre, Block E, Level 4, Clayton Road, Clayton, Victoria 3168, Australia \\ (Requests for offprints should be addressed to A Corbould; Email: anne.corbould@princehenrys.org)
}

\begin{abstract}
Adipose tissue plays a central role in determining whole body insulin sensitivity. Several aspects of adipose cell function are regulated by androgens. Given that high androgen levels and insulin resistance are linked in women, we proposed that androgens may influence insulin-mediated glucose metabolism in adipose cells. Preadipocytes harvested from s.c. adipose tissue of healthy women aged $37 \pm 5$ years were differentiated in vitro, then treated with testosterone $(\mathrm{T})$ and/or androgen receptor (AR) antagonists (cyproterone acetate, flutamide) for $48 \mathrm{~h}$. Maximal insulin-stimulated glucose uptake (insulin $10 \mathrm{nM}$ ) and increment following insulin stimulation were significantly impaired in cells treated with T 10 and $100 \mathrm{nmol} / \mathrm{l}$. This defect was abolished by cyproterone acetate and partially reversed by flutamide. The effect of $\mathrm{T}$ could not be accounted for by altered differentiation status of the adipocytes. In the glucose
\end{abstract}

metabolic pathway of insulin signaling, treatment of cells with $\mathrm{T} 10 \mathrm{nmol} / \mathrm{l}$ did not alter insulin-stimulated phosphorylation of insulin receptor substrate-1 or Akt, but insulin-stimulated phosphorylation of protein kinase C (PKC) $\zeta$ was impaired. Insulin signaling via the mitogenic/gene regulatory pathway, as assessed by extracellular signalregulated kinase phosphorylation, was unchanged. We conclude that (1) $\mathrm{T}$, or an androgenic metabolite of $\mathrm{T}$, induces insulin resistance in adipocytes of women, selective for metabolic signaling pathways; (2) this defect is via AR; and (3) the defect in signaling is independent of phosphatidylinositol 3-kinase activation and involves impaired phosphorylation of PKC $\zeta$. These findings are relevant to understanding the pathogenesis of insulin resistance in hyperandrogenic women.

Journal of Endocrinology (2007) 192, 585-594

\section{Introduction}

Adipose tissue is now recognized to play a central role in determining whole body insulin sensitivity (Minokoshi et al. 2003). In animal models, insulin resistance in adipose tissue secondarily results in insulin resistance in skeletal muscle (Abel et al. 2001, Yang et al. 2005). In the insulin-resistant states of obesity (Stolic et al. 2002), type 2 diabetes mellitus (DM; Smith et al. 1999), and polycystic ovary syndrome (PCOS; Ciaraldi et al. 1992, Dunaif et al. 1992, Marsden et al. 1994), insulinstimulated glucose uptake in isolated adipocytes or adipose tissue explants is impaired due to post-insulin receptor defects in signal transduction. The precise molecular mechanisms of these signaling defects are unknown, but it is likely that both genetic and in vivo environmental factors are involved.

Androgens regulate several aspects of adipose cell function including lipid metabolism and differentiation. Androgens bind to the androgen receptor (AR), which mediates most of its physiological functions through transcriptional activation of downstream genes. Functional ARs are present in human adipose tissue, both in stromal cells and mature adipocytes (Pedersen et al. 1996) and in preadipocytes which have been differentiated in vitro (Dieudonné et al. 1998). Androgens have been shown to regulate lipolysis and lipogenesis in the adipose cells of women. In s.c. preadipocytes which have been differentiated in vitro, testosterone $(\mathrm{T})$ inhibited catecholamine-stimulated lipolysis associated with decreased expression of hormone-sensitive lipase (HSL) and $\beta 2-$ adrenoceptors (Dicker et al. 2004). The more biologically potent metabolite of $\mathrm{T}$, dihydrotestosterone (DHT), also modulated expression of HSL and lipoprotein lipase (LPL) in isolated s.c. adipocytes of women (Anderson et al. 2002). In animal models, prenatal exposure of females to androgens resulted in increased adiposity (Eisner et al. 2003) and alterations in adipose tissue lipolysis (Reiling et al. 1997) in adulthood, raising the possibility that androgens have a programming effect on adipose tissue. Androgens do not appear to influence preadipocyte proliferation, at least in the rat (Dieudonné et al. 2000), but in both rat adipose cells (Dieudonné et al. 2000) and 3T3-L1 adipocytes (Singh et al. 2006), androgens inhibited adipogenic differentiation. However, whether androgens play a role in the regulation of a key adipose cell metabolic function, insulin-mediated glucose uptake, has not been investigated. 
Insulin-mediated glucose transport is dependent on translocation of the glucose transporter GLUT4 to the cell membrane. In adipocytes, stimulation of glucose uptake via GLUT4 involves at least two pathways: (1) insulin receptor substrate (IRS)-1-dependent activation of phosphatidylinositol (PI) 3-kinase and downstream targets Akt/protein kinase $\mathrm{B}(\mathrm{PKB})$ and atypical protein kinase $\mathrm{C}(\mathrm{aPKC})$ isoforms $\zeta / \lambda$ and (2) the less understood non-IRS-PI3kinase-dependent activation of the $\mathrm{Cbl} / \mathrm{CAP}$ pathway (reviewed by Ishike \& Klip 2005). The major aPKC in human in vitro-differentiated adipocytes that mediates the effects of insulin on glucose transport is PKC (Bandyopadhyay et al. 2002). Insulin action on glucose uptake is initiated by activation of the insulin receptor tyrosine kinase that results in phosphorylation of IRS-1 on tyrosine residues. These phosphotyrosine residues act as docking sites for SH2 domain-containing proteins, including PI3-kinase (White \& Yenush 1998). The phosphorylated IRS-1 tyrosine 612 is a key site for PI3-kinase activation (Esposito et al. 2001). Insulin also has mitogenic/gene regulatory actions, mediated by activation of the mitogen-activated protein kinase (MAPK) signaling cascade via Ras, Raf, and extracellular signalregulated kinase (ERK) activation (Cobb 1999).

The objective of this study was to examine the effect of androgens on insulin-mediated glucose transport and insulin signaling in adipose cells of women. We postulated that androgens could be an in vivo environmental factor that contributes to insulin resistance in the adipose cells of women, with implications for women with androgen excess, particularly polycystic ovary syndrome (PCOS), a common cause of insulin resistance associated with hyperandrogenemia (Dunaif 1997).

\section{Materials and Methods}

\section{Cell culture}

Subcutaneous adipose tissue was obtained from healthy women aged less than 50 years (age $37 \pm 5$ years, mean \pm s.D.) undergoing elective abdominoplasty. The study was approved by the institutional Human Research and Ethics Committee and all patients gave written informed consent. Stromal cells were isolated from fresh tissue by collagenase digestion (Rodbell 1964) and primary cultures were seeded at a density of $\sim 2 \times 10^{5}$ cells/ $\mathrm{ml}$ in DMEM (Gibco BRL Life Technologies) containing $10 \%$ fetal bovine serum (FBS; JRH Biosciences, Lenexa, KS, USA) plus penicillin and streptomycin (Gibco). At confluence, the cultures were washed in PBS and placed in adipogenic medium Dulbecco's modified Eagle's medium (DMEM) without phenol red, 3\% charcoal-stripped FBS (HyClone, Logan, UT, USA), $1 \mu \mathrm{mol} / 1$ troglitazone (gift of Parke-Davis, Morris Plains, NJ, USA), $25 \mathrm{nmol} / 1$ regular insulin (Novo Nordisk, Baulkham Hills, NSW, Australia), $1 \mu \mathrm{mol} / 1$ dexamethasone (Sigma-Aldrich Corp., St Louis, MO, USA), $200 \mathrm{pmol} / \mathrm{l}$ triiodothyronine (Sigma), and $0.5 \mathrm{mmol} / 1$
Isobutyl-1-methylxanthine (IBMX; Sigma). The medium was replaced after 4 days, omitting troglitazone and IBMX, and again after a further 4 days, omitting dexamethasone. After a total of 12 days in adipogenic medium, at which time $70-90 \%$ of the cells contained multiple lipid droplets, the cultures were washed with PBS and incubated in DMEM (low glucose, without phenol red) with $0 \cdot 1 \%$ BSA (Cohn modified: ICN, Costa Mesa, CA, USA) for $48 \mathrm{~h} \pm$ vehicle (maximum $0 \cdot 01 \%$ ethanol), $\mathrm{T}(10,100 \mathrm{nmol} / \mathrm{l})$, and/or AR antagonists (flutamide $(1 \mu \mathrm{mol} / \mathrm{l})$ or cyproterone acetate (CPA; $1 \mu \mathrm{mol} / \mathrm{l}$; Sigma)). The same lots of FBS and BSA were used for all experiments.

\section{Reverse transcription PCR}

Total RNA was prepared from cultured adipocytes and AR-positive (LnCaP) and AR-negative (HepG2, L6, PNT1a) cell lines using an RNA Kit (Qiagen). First strand cDNA synthesis was preformed using avian myeloblastosis virus reverse transcriptase primed by random hexamers (Promega). PCRs were carried out using the following primer sets $\left(1 \mu \mathrm{M}\right.$ final concentration; $\left.5^{\prime} \rightarrow 3^{\prime}\right)$ : AR forward TGTCGTCTTCGGAAATGTTATG, reverse GTCGGGC TGGTTGTTGTCGTG and cyclophylin forward CTT GGGCCGCGTCTCCTTC, reverse TGCCGCCAGT GCCATTAT. Thermal cycling conditions were $94{ }^{\circ} \mathrm{C}$ for 2 min followed by 40 cycles of $94{ }^{\circ} \mathrm{C}$ for $30 \mathrm{~s}, 60{ }^{\circ} \mathrm{C}$ for $30 \mathrm{~s}$, $72{ }^{\circ} \mathrm{C}$ for $14 \mathrm{~s}$, and on the final cycle, $72{ }^{\circ} \mathrm{C}$ for $10 \mathrm{~min}$.

\section{Glucose transport assay}

Glucose uptake in three replicate wells for each condition was measured in adipocytes treated as above \pm insulin $0 \cdot 1,1$, $10 \mathrm{nmol} / \mathrm{l}$ for $90 \mathrm{~min}$ (Ciaraldi et al. 1995). Specific glucose transport over $10 \mathrm{~min}$ was calculated in each well by measuring $\left[{ }^{3} \mathrm{H}\right]$-deoxy-D-glucose (Perkin-Elmer, Boston, MA, USA) incorporation and subtracting $\mathrm{L}_{-}\left[{ }^{14} \mathrm{C}\right]$-glucose (Perkin-Elmer) incorporation to correct for non-GLUTmediated glucose uptake. Protein content was measured in each well (bicinchonic acid (BCA) assay; Pierce Biotechnology, Rockford, IL, USA) and glucose uptake expressed as $\mathrm{pmol} / \mathrm{min}$ per $\mathrm{mg}$ protein.

\section{Immunoblotting}

Cultured adipocytes were incubated in serum-free medium plus treatments for $48 \mathrm{~h}$, followed by incubation in the same medium \pm insulin $(10 \mathrm{nmol} / 1,10 \mathrm{~min})$, then scraped on ice in lysis buffer ( $25 \mathrm{mmol} / 1$ Tris- $\mathrm{HCl}$ ( $\mathrm{pH} 7 \cdot 4), 0 \cdot 5 \mathrm{mmol} / 1$ EGTA, $25 \mathrm{mmol} / 1 \mathrm{NaCl}, 1 \%$ Nonidet P-40, $1 \mathrm{mmol} / 1 \mathrm{Na}_{3} \mathrm{VO}_{4}$, $10 \mathrm{mmol} / 1 \mathrm{NaF}, 0 \cdot 2 \mathrm{mmol} / 1$ leupeptin, $1 \mathrm{mmol} / \mathrm{l}$ benzamidine, and $0.1 \mathrm{mmol} / 1$ 4-(2-aminoethyl)benzenesulfonyl fluoride hydrochloride). Lysates were solubilized by rocking (40 min, $4{ }^{\circ} \mathrm{C}$ ), then centrifuged for $15 \mathrm{~min}$ at $13000 \mathrm{~g}$, and supernatants stored at $-80^{\circ} \mathrm{C}$. Protein content was determined by BCA protein assay. Lysates (25-50 $\mu \mathrm{g}$ protein) were resolved by SDS-PAGE and immunoblotted with specific antibodies to 
insulin receptor $\beta$-subunit (IR $\beta$; Transduction Laboratories, San Diego, CA, USA), GLUT1/4 (Chemicon, Temecula, CA, USA, USA), acetyl-CoA carboxylase (ACC; Cell Signaling Technology, Beverly, MA, USA), IRS-1 (Upstate Biotechnology, Lake Placid, NY, USA), phospho-IRS-1 Tyr $^{612}$ (Biosource, Camarillo, CA, USA), Akt and phosphoAkt $\operatorname{Ser}^{473}$ (Cell Signaling), PKC $\zeta$ (Santa Cruz Biotechnology, Santa Cruz, CA, USA), phospho-PKC $/ \lambda \mathrm{Thr}^{410 / 403}$ (Cell Signaling), ERK1/2 and phospho-ERK1/2 $\mathrm{Thr}^{202} / \mathrm{Tyr}^{204}$ (Cell Signaling), and appropriate fluorophore-conjugated secondary antibodies (anti-rabbit (Molecular Probes, Eugene, OR, USA) or anti-mouse (Rockland Immunochemicals, Gilbertsville, PA, USA)). Immunoblots were visualized using infrared imaging (Odyssey; Li-Cor, Lincoln, NE, USA) and quantitated using Odyssey software version 1.2. An internal standard was loaded on all immunoblots and results expressed as percentage of standard.

\section{IRS-1-associated PI3-kinase activity assay}

Lysates were subjected to immunoprecipitation with IRS-1 antibodies at $4{ }^{\circ} \mathrm{C}$ for $4 \mathrm{~h}$, coupled to protein A sepharose beads, and PI3-kinase activity measured as described (Goodyear et al. 1995) with resolution of product using thin layer chromatography and quantitation using a phosphorimager.

\section{Quantification of lipid accumulation in differentiated cells}

The percentage of cells accumulating multiple lipid droplets during differentiation was monitored by phase contrast microscopy. Additionally, Oil Red O retention in the cells was measured adapting the method of Singh et al. (2006): duplicate wells of differentiated cells which had been incubated in serum-free media with or without $\mathrm{T}$ for $48 \mathrm{~h}$ were fixed in $2 \%$ formaldehyde for $15 \mathrm{~min}$, stained with Oil Red O $(0 \cdot 5 \%)$ for $1 \mathrm{~h}$, then extracted with $4 \%$ Ipegal in isopropanol for $15 \mathrm{~min}$ and absorbance measured by spectrophotometry at $490 \mathrm{~nm}$.

\section{Statistical analysis}

Treatments were compared using repeated measures ANOVA with post hoc Dunnett's multiple comparison test. Withingroup comparisons were made using two-tailed $t$-tests or Wilcoxon signed rank test when the size of the sample group was $\leq 6$. Data were presented as mean \pm s.E.M. and differences were considered to be significant at $P<0 \cdot 05$.

\section{Results}

\section{AR expression in cultured adipocytes of women}

Consistent with published reports (Pedersen et al. 1996, Dieudonné et al. 1998), expression of AR was confirmed in cultured adipocytes using RT-PCR (Fig. 1).

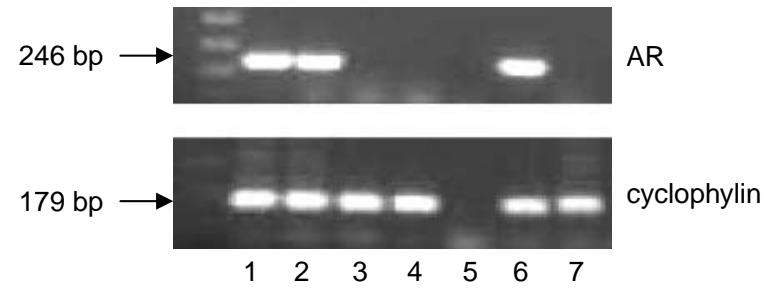

Figure 1 Expression of androgen receptor (AR) in cultured adipocytes of women and various cell lines using RT-PCR. A representative gel ( $1 \%$ agarose, stained with ethidium bromide) is shown. Lane 1, adipocytes patient 1; lane 2, adipocytes patient 2; lane 3, HepG2 cells; lane 4, L6 cells; lane 5, no DNA control; lane 6, LnCaP cells; lane 7, PNT1a cells.

\section{Effect of androgens and androgen receptor antagonists on glucose transport}

Maximal insulin-stimulated glucose uptake was significantly reduced by $\mathrm{T}$ treatment: $\mathrm{T} 10 \mathrm{nmol} / \mathrm{l}$ reduced maximal glucose transport by $23 \%$ and $\mathrm{T} 100 \mathrm{nmol} / 1$ by $30 \%$ when compared with vehicle $(n=7 /$ treatment group, $P<0 \cdot 01$; Fig. 2a). Basal glucose transport was reduced by $\sim 15 \%$ in cells treated with T $100 \mathrm{nmol} / \mathrm{l}$ when compared with vehicle $(P<0 \cdot 05)$, but was not altered in cells treated with T $10 \mathrm{nmol} / 1$ (Fig. 2a). The increment of glucose uptake after maximal insulin stimulation (i.e. glucose uptake at baseline subtracted from glucose uptake at $10 \mathrm{nmol} / 1$ insulin) was reduced by $50-60 \%$ in the T-treated cells $(P<0 \cdot 01, \mathrm{~T} 10 \mathrm{nmol} / 1$ versus vehicle; $P<0 \cdot 05$, T $100 \mathrm{nmol} / 1$ versus vehicle), consistent with the induction of insulin resistance (Fig. 2b).

Concurrent treatment with CPA abolished the effect of $\mathrm{T}$ $100 \mathrm{nmol} / 1$ on insulin-stimulated glucose uptake (Fig. 2d) and on increment of glucose uptake to maximal insulin stimulation (Fig. 2e; $n=6 /$ treatment group). The effects of CPA were similar in the cells treated with $\mathrm{T} 10 \mathrm{nmol} / \mathrm{l}$, although the changes did not reach statistical significance (Fig. $2 \mathrm{c}$ and e). The effect of concurrent treatment with flutamide on glucose uptake in adipocytes treated with $\mathrm{T} 10$ or $100 \mathrm{nmol} / \mathrm{l}$ was also assessed $(n=7 /$ treatment group). Flutamide alone resulted in lower insulin-stimulated glucose uptake than in vehicle-treated cells, suggestive of a partial agonist effect, although this change did not reach statistical significance (Fig. 2f-h). In adipocytes treated with T $10 \mathrm{nmol} / 1$, flutamide partially corrected the defect in insulinstimulated glucose uptake (Fig. 2f; $P=$ not significant (NS)). A similar non-significant effect of flutamide was seen in cells treated with T $100 \mathrm{nmol} / \mathrm{l}$, although this effect was attenuated at the maximal insulin concentration (10 nmol/l; Fig. $2 \mathrm{~g})$.

\section{Effects of testosterone on adipocyte differentiation}

In order to determine whether the impairment of glucose uptake in cultured adipocytes treated with $\mathrm{T}$ could be attributed to de-differentiation of the adipocytes, the abundance of differentiation-dependent proteins as well as lipid content of the cells was measured. Incubation of cultured preadipocytes in adipogenic medium for 12 days resulted in a 
(a) Glucose uptake: T

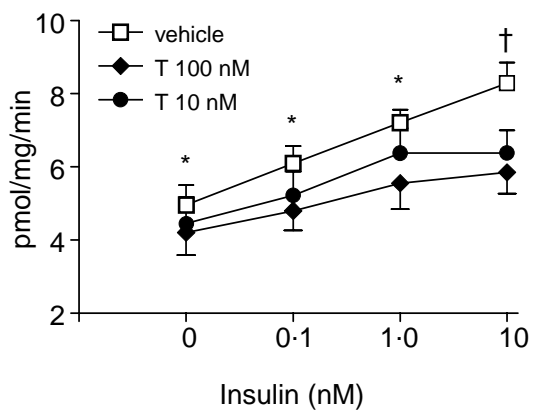

(c)

$$
\mathrm{T} 10 \mathrm{nM}+\mathrm{CPA}
$$

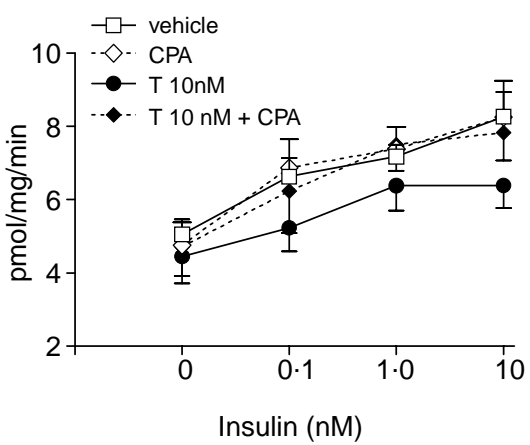

(f)

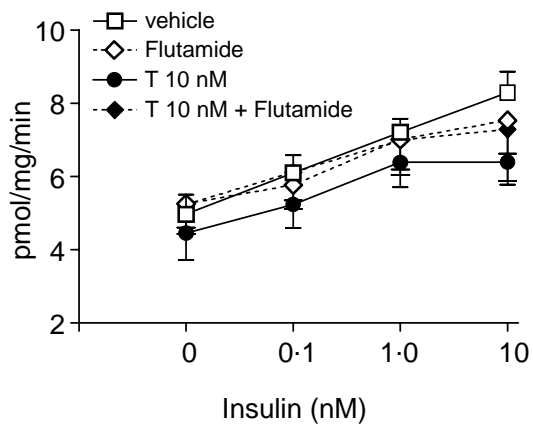

(b) Increment: $T$

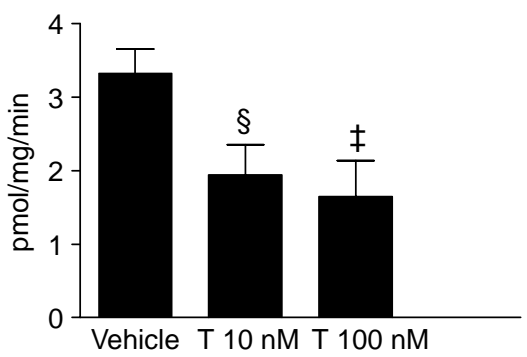

(d)

$\mathrm{T} 100 \mathrm{nM}+\mathrm{CPA}$

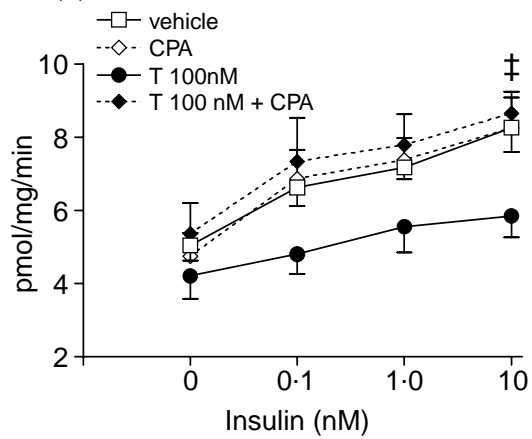

(e)

Increment: T + CPA

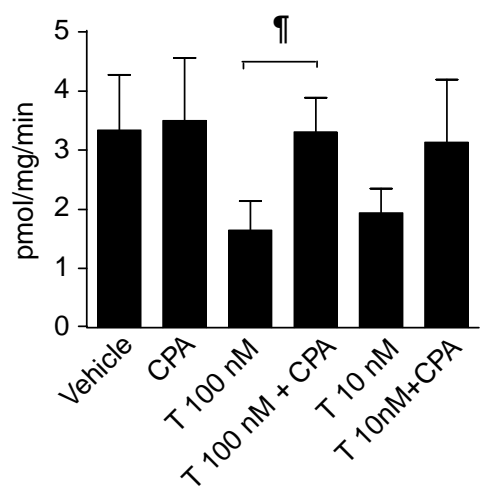

(h) Increment: T + Flutamide

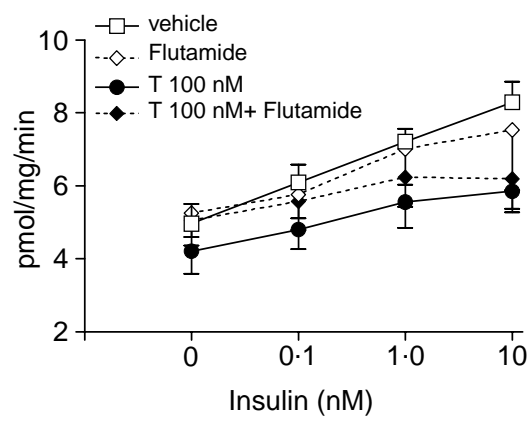

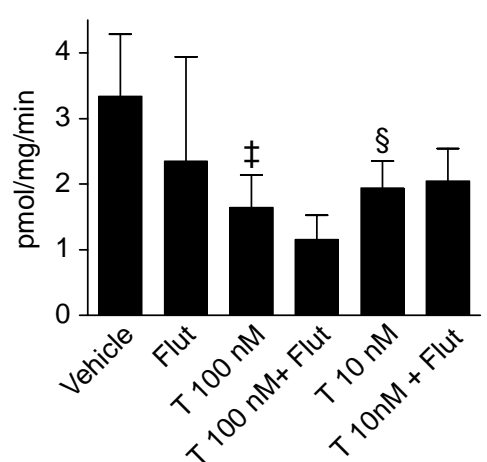

Figure 2 Effect of testosterone $(\mathrm{T})$ and androgen receptor antagonists (cyproterone acetate, CPA; flutamide, Flut) on insulin-stimulated glucose uptake in cultured adipocytes of women. Subcutaneous abdominal preadipocytes were incubated in adipogenic medium for 12 days, followed by treatment for $48 \mathrm{~h}$ with or without Tand CPA or flutamide. Glucose uptake (insulin 0-10 nmol/l) was measured in cells treated with testosterone (T; $10 \mathrm{nmol} / \mathrm{l}, 100 \mathrm{nmol} / \mathrm{l} ; n=7 /$ treatment group) (a). The increment (glucose uptake at baseline subtracted from glucose uptake at $10 \mathrm{nmol} / \mathrm{l}$ insulin) of the response to insulin was calculated (b). The effect of CPA on glucose uptake was measured in adipocytes ( $n=6 /$ treatment group) treated with or without CPA $(1 \mu \mathrm{mol} / \mathrm{l})$ and T $10 \mathrm{nmol} / \mathrm{l}$ (c and e) or T $100 \mathrm{nmol} / \mathrm{l}$ (d and e) for $48 \mathrm{~h}$. The effect of flutamide (Flut) on glucose uptake was measured in adipocytes ( $n=7 /$ treatment group) treated with or without flutamide $(1 \mu \mathrm{mol} / \mathrm{l})$ and T $10 \mathrm{nmol} / \mathrm{l}(\mathrm{f}$ and h) or T $100 \mathrm{nmol} / \mathrm{l}$ (g and $\mathrm{h}$ ) for $48 \mathrm{~h}$. Data are expressed as means \pm s.E.M. ${ }^{*} P<0 \cdot 05, \mathrm{~T} 100 \mathrm{nmol} / \mathrm{l}$ versus vehicle; ${ }^{\dagger} P<0 \cdot 01, \mathrm{~T} 10 \mathrm{nmol} / \mathrm{l}$ and T $100 \mathrm{nmol} / \mathrm{l}$ versus vehicle. ${ }^{\ddagger} P<0 \cdot 05, \mathrm{~T}$ versus vehicle; ${ }^{\S} P<0 \cdot 01, \mathrm{~T}$ versus vehicle. ${ }^{\Uparrow} P<0 \cdot 05, \mathrm{~T} 100 \mathrm{nmol} / \mathrm{l}$ versus $\mathrm{T} 100 \mathrm{nmol} / \mathrm{I}+\mathrm{CPA}$.

marked increase in abundance of IR $\beta$, GLUT4, and ACC (Fig. 3a). The abundance of these proteins was not altered when cultured adipocytes $(n=5 /$ treatment group) were incubated with $\mathrm{T} 10$ or $100 \mathrm{nmol} / \mathrm{l}$ for $48 \mathrm{~h}$ (Fig. 3b).
GLUT1 abundance was also unchanged in T-treated adipocytes (Fig. 3c). Similarly, the lipid content of the cells was not affected by incubation with $\mathrm{T}$ for $48 \mathrm{~h}(n=5 /$ treatment group; Fig. 3d). 
(a)

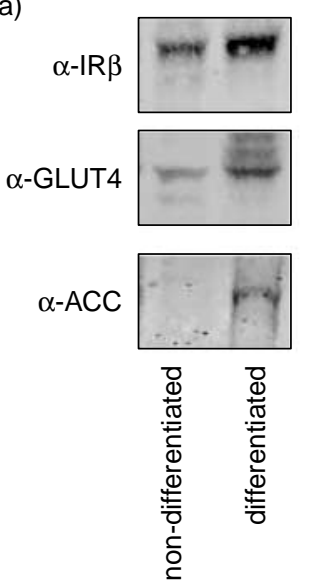

(b)

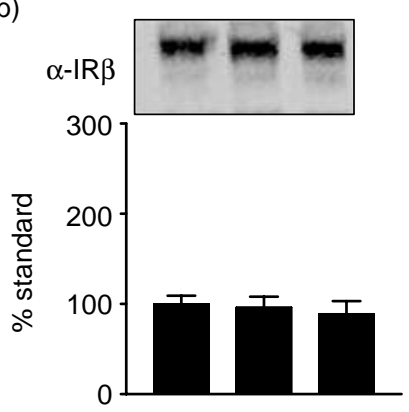

(c)

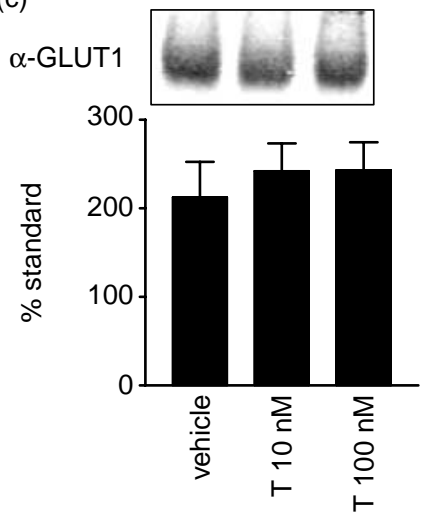

(d)

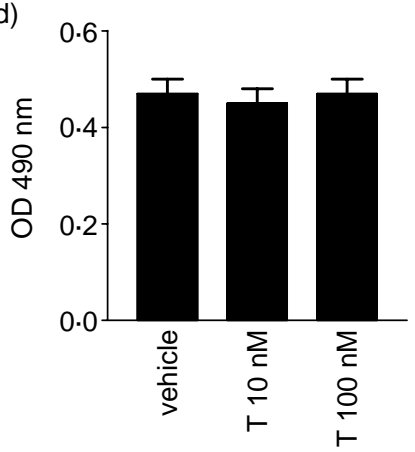

Figure 3 Effect of Ton markers of adipocyte differentiation. IR $\beta$, GLUT4, and ACC are differentiationdependent proteins in adipocytes: representative western blots of these proteins in undifferentiated cells versus cells incubated in adipogenic media for 12 days are shown (a). Abundance of IR $\beta$, GLUT4, and ACC ( $n=5 /$ treatment group) (b) and GLUT1 ( $n=4 /$ treatment group) (c) by western blotting in in vitro-differentiated adipocytes treated with $\mathrm{T}(10 \mathrm{or} 100 \mathrm{nmol} / \mathrm{l})$ for $48 \mathrm{~h}$. Data are expressed as means \pm S.E.M. (\% of internal standard). Quantitation of lipid content of cultured adipocytes treated with T for $48 \mathrm{~h}$ by elution of Oil Red O and measurement of OD $490 \mathrm{~nm}$ ( $n=5 /$ treatment group) (d).

\section{Insulin signaling via IRS-1 and PI3-kinase}

Insulin signaling via IRS-1 was assessed only in cultured adipocytes treated with $\mathrm{T} 10 \mathrm{nmol} / \mathrm{l}$, as the physiological relevance of higher $\mathrm{T}$ concentrations is less clear. In cultured adipocytes treated with $\mathrm{T} 10 \mathrm{nmol} / 1$ for $48 \mathrm{~h}(n=7)$, the abundance of phospho-IRS-1 $\operatorname{Tyr}^{612}$ following insulin stimulation was unchanged (Fig. 4a). Total IRS-1 abundance did not differ (Fig. 4b) and there was no significant difference in phospho-IRS-1 Tyr $^{612}$ when adjusted for total IRS-1
(Fig. 4c). Likewise, IRS-1-associated PI3-kinase activity did not differ in the T-treated cells $(n=9$; Fig. $4 \mathrm{~d})$.

\section{Insulin signaling downstream of PI3-kinase}

Insulin-stimulated phosphorylation of downstream targets of PI3-kinase, Akt/PKB, and atypical PKC isoform PKC $\zeta$ were examined in adipocytes treated with $\mathrm{T} 10 \mathrm{nmol} / \mathrm{l}$. The abundance of phosphorylated Akt following insulin stimulation and total Akt did not differ in the T-treated cells when 
(a) $\alpha$-phospho-IRS-1 Tyr 612

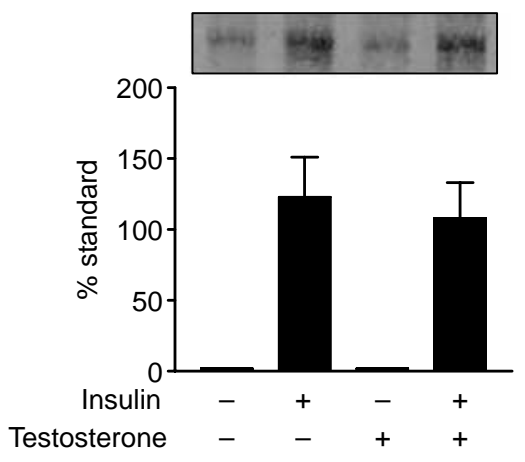

(b)

$\alpha-I R S-1$

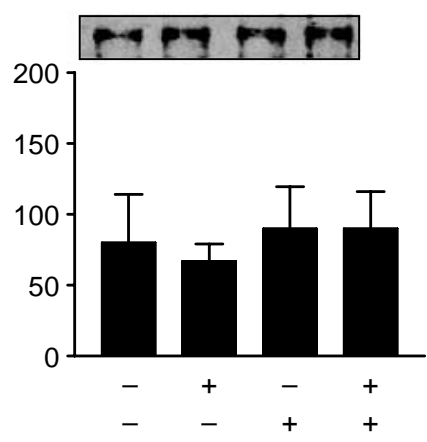

(c) phospho-IRS-1 Tyr $612 /$ total IRS-1

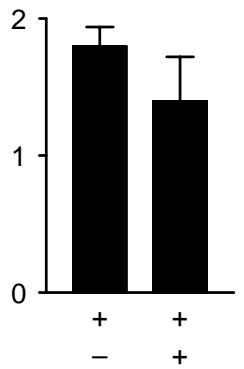

(d) IRS-1 assoc PI3-kinase activity
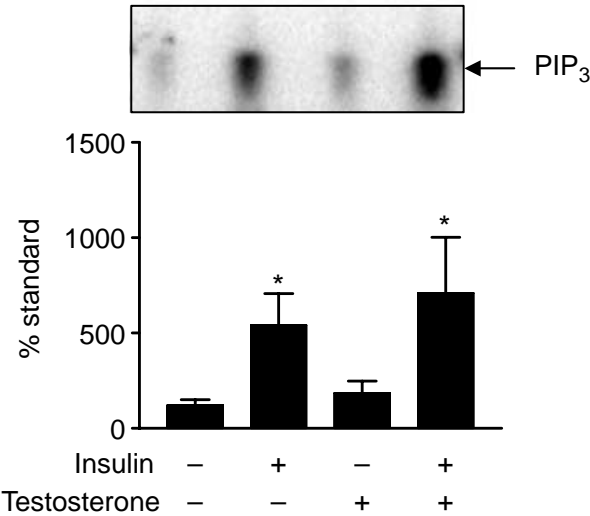

Figure 4 Insulin signaling via IRS-1 in cultured adipocytes treated with T (10 nmol/l) for $48 \mathrm{~h}$. Lysates of cells at baseline or after insulin stimulation $(10 \mathrm{nmol} / \mathrm{l}, 10 \mathrm{~min})$ were resolved by SDS-PAGE and immunoblotted with $\alpha$-phospho-IRS-1 Tyr ${ }^{612}$ or $\alpha$-IRS-1 $(n=7)(\mathrm{a}-\mathrm{C})$. PI3-kinase activity was measured in IRS-1 immunoprecipitates, with $\mathrm{PIP}_{3}$ product resolved by TLC and quantitated using a phosphorimager $(n=9)(\mathrm{d})$. Data are expressed as means \pm s.E.M. (\% of internal standard). ${ }^{*} P<0 \cdot 01$, insulin-stimulated versus baseline under the same conditions.

compared with vehicle ( $n=9$; Fig. $5 \mathrm{a}$ and b), and when expressed as phospho-Akt adjusted for total Akt, there was a non-significant increase in the T-treated cells (Fig. 5c). Insulin significantly stimulated phosphorylation of $\mathrm{PKC} \zeta$ in control cells $(P<0 \cdot 05)$, but not in T-treated cells $(n=7$; Fig. $5 \mathrm{~d})$. Total PKC $\zeta$ abundance did not differ (Fig. 5e). PhosphoPKC $\zeta$ adjusted for total PKC $\zeta$ also showed significant stimulation with insulin in vehicle-treated cells only (Fig. 5f). Although the antibodies used to detect PKC $\zeta$ also recognize $\mathrm{PKC}$ isoforms, $\lambda$ and $\tau$, cultured human adipocytes do not contain detectable amounts of PKC $\lambda / \tau$ (Bandyopadhyay et al. 2002).

\section{Insulin signaling via mitogenic pathway}

Insulin regulation of ERK phosphorylation was assessed in order to determine whether the defect in insulin-mediated glucose uptake in adipocytes treated with $\mathrm{T}$ was specific for insulin metabolic signaling pathways. Basal and insulinstimulated phospho-ERK, total ERK, and phospho-ERK adjusted for total ERK did not differ in the adipocytes treated with $\mathrm{T} 10 \mathrm{nmol} / \mathrm{l}$ when compared with vehicle $(n=12)$, consistent with intact insulin mitogenic/gene regulatory signaling in the T-treated cells (Fig. $5 \mathrm{~g}-\mathrm{i}$ ).

\section{Discussion}

The present study has demonstrated that $\mathrm{T}$ induces selective insulin resistance in cultured s.c. adipocytes of women. Chronic $\mathrm{T}$ treatment significantly impaired insulin action on glucose metabolism (as assessed by glucose uptake), but did not alter insulin action on the mitogenic/gene regulatory pathway (as assessed by ERK phosphorylation). The T-induced defect in glucose transport was associated with impaired insulin-stimulated phosphorylation of $\mathrm{PKC} \zeta$, an atypical PKC isoform downstream of PI3-kinase, which mediates the effects of insulin on glucose transport in human in vitro-differentiated adipocytes (Bandyopadhyay et al. 2002). The activation of another downstream target of PI3-kinase, 
(a)

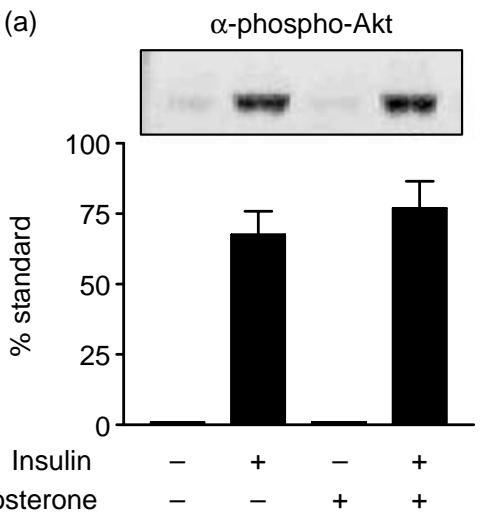

(d)

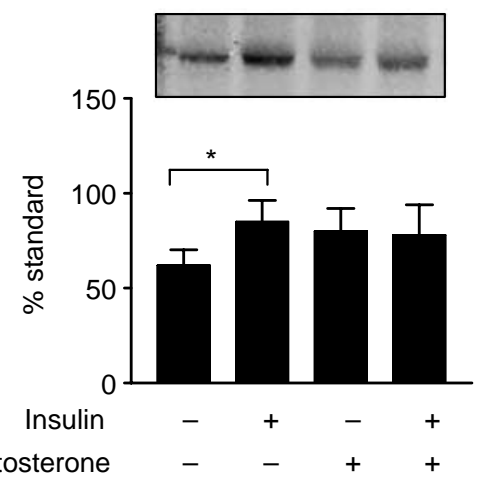

(g)

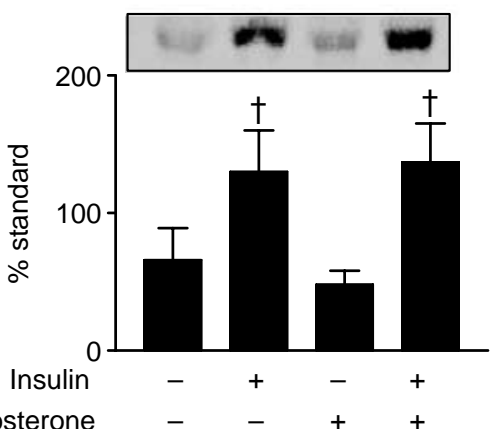

(b)
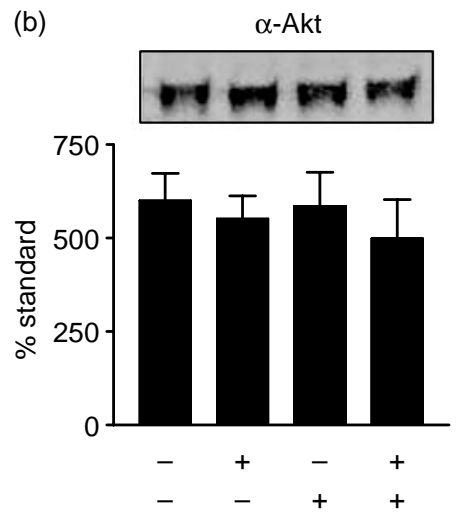

(e)

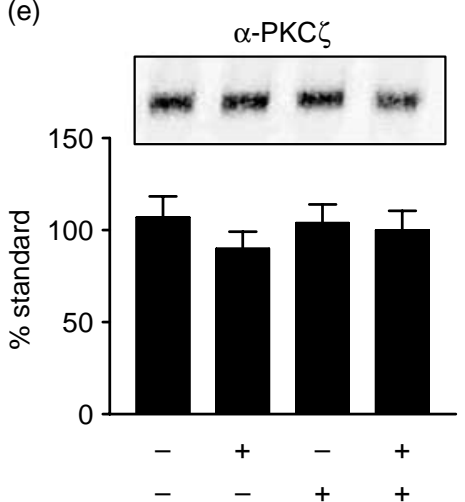

(h)

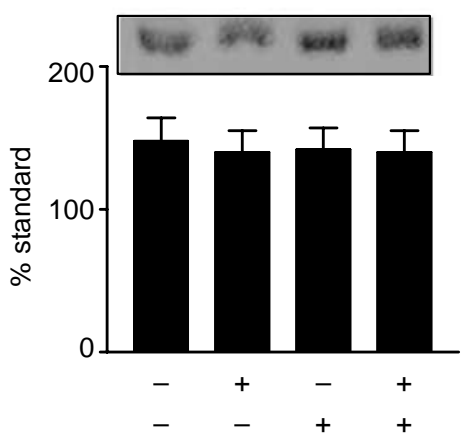

(c) phospho-Akt/

total Akt

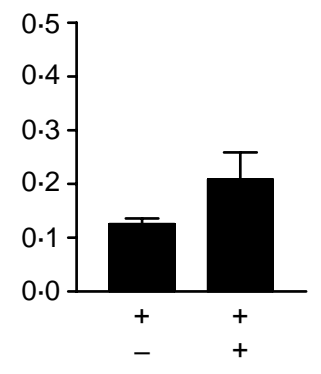

(f)

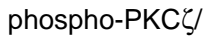
total PKC $\zeta$

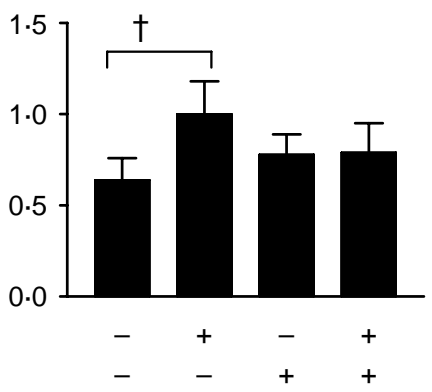

(i) phospho-ERK/ total ERK

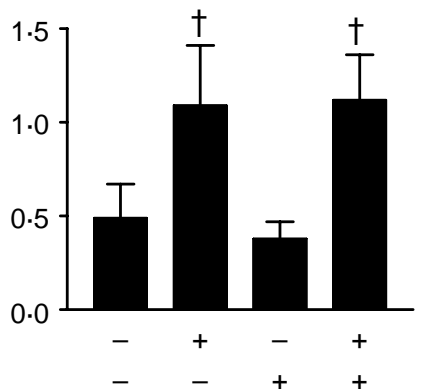

Figure 5 Insulin signaling downstream of PI3-kinase and also signaling via the mitogenic pathway in cultured adipocytes treated with $\mathrm{T}$ $(10 \mathrm{nmol} / \mathrm{l})$ for $48 \mathrm{~h}$. Lysates of cells at baseline or after insulin stimulation $(10 \mathrm{nmol} / \mathrm{l}, 10 \mathrm{~min})$ were resolved by SDS-PAGE and immunoblotted with $\alpha$-phospho-Akt and $\alpha$-total Akt $(n=9)(\mathrm{a}-\mathrm{C}), \boldsymbol{\alpha}$-phospho-PKC $\zeta$ and $\alpha$-total PKC $\zeta(n=7)(\mathrm{d}-\mathrm{f})$, or $\alpha$-phospho-ERK and $\alpha$-total ERK $(n=12)(\mathrm{g}-\mathrm{i})$. Data are expressed as means \pm s.E.M. ( $\%$ of internal standard). ${ }^{*} P<0 \cdot 05,{ }^{+} P<0 \cdot 01$, insulin-stimulated versus baseline under the same conditions.

Akt, was not impaired in the T-treated cells, and no defects in the proximal insulin signaling pathway via IRS-1 were identified. Defects in aPKC activation, due to poor responsiveness of aPKC to the lipid product of PI3-kinase, $\mathrm{PIP}_{3}$, have been reported in both skeletal muscle and adipocytes in obesity, prediabetes, and type 2 DM (Beeson et al. 2003, Farese et al. 2005), suggesting that the present finding of impaired insulin-mediated phosphorylation of PKC $\zeta$ induced by $\mathrm{T}$ in adipocytes of women is physiologically relevant.

Given that the AR antagonists cyproterone acetate and flutamide attenuated the effect of $\mathrm{T}$ on glucose uptake, it can be concluded that the action of $\mathrm{T}$ was mediated via the classical AR. Testosterone is metabolized to estradiol in 
adipose tissue catalyzed by $\mathrm{P}_{450}$ aromatase. However, it is unlikely that the effect of $\mathrm{T}$ on glucose uptake was estrogen mediated, given both the response to AR antagonists and the low expression of aromatase in in vitro-differentiated human adipocytes (Clyne et al. 2002). Testosterone is also metabolized to the significantly more biologically active androgen DHT, catalyzed by $5 \alpha$-reductase. This enzyme is expressed in adipose tissue (Martel et al. 1994). Thus, it is possible that the effects of $\mathrm{T}$ observed in the present studies were at least partially mediated by conversion to DHT.

Androgens have been shown to inhibit adipogenesis in rodent adipose cells (Dieudonné et al. 2000, Singh et al. 2006). However, supraphysiological $\mathrm{T}(1 \mu \mathrm{mol} / \mathrm{l})$ used for 10 days during in vitro differentiation of adipose cells of women did not alter the differentiation status of the cells, as indicated by glycerol-3-phosphate dehydrogenase activity (Dicker et al. 2004). In the present study, cells were treated with $T$ for $48 \mathrm{~h}$ at the completion of 12-day incubation in adipogenic medium. The expression of proteins IR $\beta$ (Smith et al. 1988) and GLUT4 (Hauner et al. 1998), the abundance of which increases markedly during the differentiation of preadipocyte to adipocyte, and ACC, an enzyme with a central role in fatty acid metabolism (Ruderman et al. 2003) did not differ in the T-treated and control cells. The lipid content of the T-treated cells was also unchanged. The defect in insulin-mediated glucose uptake observed in the T-treated adipocytes could not therefore be accounted for by an effect on the degree of adipocyte differentiation, suggesting a specific action of $\mathrm{T}$ on adipocyte metabolism.

The post-AR pathway whereby $\mathrm{T}$ caused impairment of insulin-mediated glucose uptake and phosphorylation of PKC $\zeta$ in adipocytes of women remains to be elucidated. While the mechanisms for androgen effects in tissues such as prostate have been extensively studied, there is little information on androgen actions in human adipose tissue, although novel pathways are now being identified, for example, interaction of $\mathrm{AR}$ with $\beta$-catenin and activation of Wnt signaling (Singh et al. 2006). Although the present studies have focused on the insulin signaling pathway, androgens could potentially modulate multiple pathways involved in cellular metabolism with consequences for insulin sensitivity, including AMP-activated protein kinase (AMPK), an enzyme with a central role in cellular energy balance and lipid oxidation (Ruderman et al. 2003) that has also been shown to activate aPKC $\zeta$ (Chen et al. 2002, Luna et al. 2006).

In the present studies, T $10 \mathrm{nmol} / \mathrm{l}$ for $48 \mathrm{~h}$ had significant effects on insulin-stimulated glucose uptake in adipocytes. Whether lower $\mathrm{T}$ concentrations have a similar effect is unknown. Although T $10 \mathrm{nmol} / \mathrm{l}$ is higher than the normal female circulating concentration, the $\mathrm{T}$ concentration within the adipose tissue of women approaches this level (Deslypere et al. 1985). Thus, $\mathrm{T} 10 \mathrm{nmol} / \mathrm{l}$ is not significantly supraphysiological. The local $\mathrm{T}$ concentration in the adipose tissue of women with hyperandrogenemia is not known, but is conceivably even higher than $10 \mathrm{nmol} / \mathrm{l}$. The present studies examined the effects of chronic androgen treatment of adipose cells because the in vivo situation in women with hyperandrogenemia is one of sustained increases in androgen levels rather than rapid fluctuations. Rapid effects of androgens via non-genomic mechanisms have been characterized in various cell types (Simoncini \& Genazzani 2003), although not yet in human adipose tissue, and the relevance of these effects to the in vivo situation is unclear.

The present studies may be relevant to understanding why hyperandrogenism and insulin resistance are associated in women. High $\mathrm{T}$ levels have been linked to multiple cardiovascular disease (CVD) risk factors in women (Oh et al. 2002, Korytkowski et al. 2005). Low levels of sexhormone-binding globulin (SHBG), a plasma protein that regulates bioavailability of circulating $\mathrm{T}$, have been independently linked with CVD in women (Reinecke et al. 2002). Untreated women with androgen excess due to non-classic congenital adrenal hyperplasia (21-hydroxylase deficiency) have reduced insulin sensitivity (Speiser et al. 1992, Saygili et al. 2005). Short-term Tadministration to female adult mice causes impaired insulin-stimulated glucose uptake in skeletal muscle (Holmäng et al. 1992), although there have been no similar studies in adipose tissue. Taken together, these lines of evidence suggest that androgens play a role in the regulation of insulin sensitivity in women and implicate elevated androgen levels in the development of insulin resistance and associated risk of CVD.

The most common cause of androgen excess in women is PCOS, due to both intrinsic upregulation of steroidogenesis (Nelson et al. 1999) and augmentation of androgen production by high circulating insulin levels (Nestler et al. 1998). In addition, PCOS is characterized by ovulatory dysfunction and insulin resistance (Dunaif 1997). Insulin resistance in PCOS has been characterized in skeletal muscle where the pathogenesis involves both intrinsic, presumably genetic, post-receptor defects in insulin metabolic signaling, as well as acquired defects due to in vivo environmental factors (Dunaif et al. 2001, Corbould et al. 2005, 2006). Adipocytes from women with PCOS also have post-insulin receptorbinding resistance to insulin effects on glucose uptake (Ciaraldi et al. 1992, Dunaif et al. 1992, Marsden et al. 1994). In women with hyperandrogenemia, insulin resistance, assessed by hyperinsulinemic-euglycemic clamp, is to some extent reversible by treatment with AR antagonists or agents that suppress ovarian steroidogenesis (Moghetti et al. 1996, Dahlgren et al. 1998). These studies suggest that a high circulating androgen level may be an in vivo environmental factor contributing to insulin resistance in PCOS, although other studies have given conflicting results (Dunaif et al. 1990, Lasco et al. 1995). In a recent study of adolescent girls with PCOS, serum androgen levels were an independent risk factor for metabolic syndrome (Coviello et al. 2006). It remains possible that hyperandrogenism in PCOS is part of a vicious cycle whereby hyperinsulinemia promotes increased androgens, which in turn contribute to insulin resistance in adipose tissue. Given that in animal models, insulin resistance in adipose tissue secondarily results in insulin resistance in 
skeletal muscle (Abel et al. 2001, Yang et al. 2005), the present data suggest an indirect mechanism whereby androgens could contribute to skeletal muscle insulin resistance in women with hyperandrogenemia.

In conclusion, this study has shown that chronic $\mathrm{T}$ treatment of in vitro-differentiated adipose cells in women results in insulin resistance, which is selective for glucose uptake, with intact mitogenic/gene regulatory signaling. Insulin signaling via IRS-1 was not impaired, but a downstream defect in insulin-stimulated phosphorylation of PKC $\zeta$ was identified in the T-treated adipocytes. The effects of $\mathrm{T}$ on glucose uptake were AR mediated, but the post-AR pathway for these effects remains to be identified. These findings are relevant to understanding the pathogenesis of insulin resistance in women with hyperandrogenism, especially PCOS, and suggest that the contribution of androgens to the metabolic defects in these conditions warrants further study.

\section{Acknowledgements}

This study was funded by grants from NHMRC Australia and Novo Nordisk Regional Diabetes Research Support Scheme. The author declares that there is no conflict of interest that would prejudice the impartiality of this scientific work.

\section{References}

Abel ED, Peroni O, Kim JK, Kim Y-B, Boss O, Hadro E, Minnemann T, Shulman GI \& Kahn BB 2001 Adipose-selective targeting of the GLUT4 gene impairs insulin action in muscle and liver. Nature 409 729-733.

Anderson LA, McTernan PG, Harte AL, Barnett AH \& Kumar S 2002 The regulation of HSL and LPL expression by DHT and flutamide in human subcutaneous adipose tissue. Diabetes, Obesity and Metabolism 4 209-213.

Bandyopadhyay G, Sajan MP, Kanoh Y, Standaert ML, Quon MJ, Lea-Currie $R$, Sen A \& Farese RV 2002 PKC- $\zeta$ mediated insulin effects on glucose transport in cultured preadipocyte-derived human adipocytes. Journal of Clinical Endocrinology and Metabolism 87 716-723.

Beeson M, Sajan MP, Dizon M, Gregenev D, Gomez-Daspet J, Miura A, Kanoh Y, Powe J, Bandyopadhyay G, Standaert ML et al. 2003 Activation of protein kinase $\mathrm{C}-\zeta$ by insulin and phosphatidylinositol-3,4,5-( $\left.\mathrm{PO}_{4}\right)_{3}$ is defective in muscle in type 2 diabetes and impaired glucose tolerance. Amelioration by rosiglitazone and exercise. Diabetes 52 1926-1934.

Chen CH, Bandyopadhyay G, Sajan MP, Kanoh Y, Standaert M, Farese RV Jr \& Farese RV 2002 Activation of the ERK pathway and atypical protein kinase $\mathrm{C}$ isoforms in exercise and aminoimidazole-4-carboxamide-1- $\beta-\mathrm{D}-$ riboside (AICAR)-stimulated glucose transport. Journal of Biological Chemisty 277 23554-23562.

Ciaraldi TP, el-Roeiy A, Madar Z, Reichart D, Olefsky JM \& Yen SS 1992 Cellular mechanisms of insulin resistance in polycystic ovarian syndrome. Journal of Clinical Endocrinology and Metabolism 75 577-583.

Ciaraldi TP, Abrams L, Nikoulina S, Mudaliar S \& Henry RR 1995 Glucose transport in cultured human skeletal muscle cells. Regulation by insulin and glucose in nondiabetic and non-insulin-dependent diabetes mellitus subjects. Journal of Clinical Investigation 96 2820-2827.

Clyne CD, Speed CJ, Zhou J \& Simpson ER 2002 Liver receptor homologue-1 (LRH-1) regulated expression of aromatase in preadipocytes. Journal of Biological Chemistry 277 20591-20597.

Cobb MH 1999 MAP kinase pathways. Progress in Biophysics and Molecular Biology 71 479-500.
Corbould A, Kim Y-B, Youngren JF, Pender C, Kahn BB, Lee A \& Dunaif A 2005 Insulin resistance in the skeletal muscle of women with polycystic ovary syndrome involves both intrinsic and acquired defects in insulin signaling. American Journal of Physiology, Endocrinology and Metabolism 288 1047-1054.

Corbould A, Zhao H, Mirzoeva S, Aird F \& Dunaif A 2006 Enhanced mitogenic signaling in skeletal muscle of women with polycystic ovary syndrome. Diabetes $\mathbf{5 5}$ 751-759.

Coviello AD, Legro RS \& Dunaif A 2006 Adolescent girls with polycystic ovary syndrome have an increased risk of the metabolic syndrome associated with increasing androgen levels independent of obesity and insulin resistance. Journal of Clinical Endocrinology and Metabolism 91 492-497.

Dahlgren E, Landin K, Krotkiewski M, Holm G \& Janson PO 1998 Effects of two anti-androgen treatments on hirsutism and insulin sensitivity on women with polycystic ovary syndrome. Human Reproduction $\mathbf{1 3}$ 2706-2711.

Deslypere JP, Verdonck L \& Vermeulen A 1985 Fat tissue: a steroid reservoir and site of steroid metabolism. Journal of Clinical Endocrinology and Metabolism $61564-570$.

Dicker A, Rydén M, Näslund E, Muehlen IE, Wirén M, Lafontan M \& Arner P 2004 Effect of testosterone on lipolysis in human pre-adipocytes from different fat depots. Diabetologia 47 420-428.

Dieudonné MN, Pecquery R, Boumediene A, Leneveu MC \& Giudicells Y 1998 Androgen receptors in human preadipocytes and adipocytes: regional specificities and regulation by sex steroids. American Journal of Physiology 274 C1645-C1652.

Dieudonné MN, Pecquery R, Leneveu MC \& Giudicelli Y 2000 Opposite effects of androgens and estrogens on adipogenesis in rat preadipocytes: evidence for sex and site-related specificities and possible involvement of insulin-like growth factor 1 receptor and peroxisome proliferator-activated receptor $\gamma 2$. Endocrinology 141 649-656.

Dunaif A 1997 Insulin resistance and the polycystic ovary syndrome: mechanism and implications for pathogenesis. Endocrine Reviews 18 774-800.

Dunaif A, Green G, Futterweit W \& Dobrjansky A 1990 Suppression of hyperandrogenism does not improve peripheral or hepatic insulin resistance in the polycystic ovary syndrome. Journal of Clinical Endocrinology and Metabolism 70 699-704.

Dunaif A, Segal KR, Shelley DR, Green G, Dobrjansky A \& Licholai T 1992 Evidence for distinctive and intrinsic defects in insulin action in polycystic ovary syndrome. Diabetes $\mathbf{4 1} 1257-1266$.

Dunaif A, Wu X, Lee A \& Diamanti-Kandarakis E 2001 Defects in insulin receptor signaling in vivo in the polycystic ovary syndrome (PCOS). American Journal of Physiology, Endocrinology and Metabolism 281 E392-E399.

Eisner JR, Dumesic DA, Kemnitz JW, Colman RJ \& Abbott DH 2003 Increased adiposity in female rhesus monkeys exposed to androgen excess during early gestation. Obesity Research 11 279-286.

Esposito DL, Yunhua Li, Alessandro C \& Quon ML $2001 \mathrm{Tyr}^{612}$ and $\mathrm{Tyr}^{632}$ in human insulin receptor substrate-1 are important for full activation of insulin-stimulated phosphatidylinositol 3-kinase activity and translocation of GLUT4 in adipose cells. Endocrinology 142 2833-2840.

Farese RV, Sajan MP \& Standaert ML 2005 Atypical protein kinase C in insulin action and insulin resistance. Biochemistry Society Transactions 33 350-353.

Goodyear LJ, Giorgio F, Sherman LA, Carey J, Smith JR \& Dohm GL 1995 Insulin receptor phosphorylation, insulin receptor substrate-1 phosphorylation, and phosphatidylinositol 3-kinase activity are decreased in intact muscle strips from obese subjects. Journal of Clinical Investigation $\mathbf{9 5}$ 2195-2204.

Hauner H, Rohrig K, Spelleken M, Lui LS \& Eckel J 1998 Development of insulin-responsive glucose uptake and GLUT4 expression in differentiating human adipocyte precursor cells. International Journal of Obesity 22 448-453.

Holmäng A, Larsson BM, Brzezinska Z \& Bjorntorp P 1992 Effects of shortterm testosterone exposure on insulin sensitivity of muscles in female rats. American Journal of Physiology 262 E851-E855.

Ishike M \& Klip A 2005 Minireview: recent developments in the regulation of glucose transporter-4 traffic: new signals, locations, and partners. Endocrinology 146 5071-5078. 
Korytkowski MT, Krug EI, Daly MA, DeRiso L, Wilson JW \& Winters SJ 2005 Does androgen excess contribute to the cardiovascular risk profile in postmenopausal women with type 2 diabetes? Metabolism 54 1626-1631.

Lasco A, Cucinotta D, Gigante A, Denuzzo G, Pedulla M, Trifiletti A \& Frisina N 1995 No changes in peripheral insulin resistance in polycystic ovary syndrome after long-term reduction of endogenous androgens with leuprolide. European Journal of Endocrinology 133 718-722.

Luna V, Casauban L, Sajan MP, Gomez-Daspet J, Powe JL, Miura A, Rivas J, Standaert ML \& Farese RV 2006 Metformin improves atypical protein kinase $\mathrm{C}$ activation by insulin and phosphatidylinolistol-3,4,5-( $\left(\mathrm{PO}_{4}\right)_{3}$ in muscle of diabetic subjects. Diabetologia 49 375-382.

Marsden PJ, Murdoch A \& Taylor R 1994 Severe impairment of insulin action in adipocytes from amenorrheic subjects with polycystic ovary syndrome. Metabolism 43 1536-1542.

Martel C, Melner MH, Gagne D, Simard J \& Labrie F 1994 Widespread tissue distribution of steroid sulfatase, 3 beta-hydroxysteroid dehydrogenase/delta 5-delta 4 isomerase ( 3 beta-HSD), 17 beta-HSD, 5 alpha-reductase and aromatase activities in the rhesus monkey. Molecular and Cellular Endocrinology 104 103-111.

Minokoshi Y, Kahn CR \& Kahn BB 2003 Tissue-specific ablation of the GLUT4 glucose transporter or the insulin receptor challenges assumptions about insulin action and glucose homeostasis. Journal of Biological Chemistry 278 33609-33612.

Moghetti P, Tosi F, Castello R, Magnani CM, Negir C, Brun E, Furlani L, Caputo M \& Muggeo M 1996 The insulin resistance in women with hyperandrogenism is partially reversed by antiandrogen treatment. Journal of Clinical Endocrinology and Metabolism 81 952-960.

Nelson VL, Legro RS, Strauss JF III \& McAllister JM 1999 Augmented androgen production is a stable steroidogenic phenotype of propagated theca cells from polycystic ovaries. Molecular Endocrinology 13 946-957.

Nestler JE, Jakubowicz DJ, Falcon de Vargas A, Brik C, Quintero N \& Medina F 1998 Insulin stimulates testosterone biosynthesis by human thecal cells from women with polycystic ovary syndrome by activating its own receptor and using inositolglycan mediators as the signal transduction system. Journal of Clinical Endocrinology and Metabolism 83 2001-2005.

Oh JY, Barrett-Connor E, Wedick NM \& Wingard DL 2002 Endogenous sex hormones and the development of type 2 diabetes in older men and women: the Rancho Bernardo study. Diabetes Care 25 55-60.

Pedersen SB, Fuglsig S, Sjogren P \& Richelsen B 1996 Identification of steroid receptors in human adipose tissue. European Journal of Clinical Investigation $\mathbf{2 6}$ 1051-1056.

Reiling BA, Drackley JK, Grum LR \& Berger LL 1997 Effects of prenatal androgenization and lactation on adipose metabolism in finishing single-calf heifers. Journal of Animal Science 75 1504-1513.
Reinecke H, Bogdanski J, Woltering A, Breithardt G, Assmann G, Kerber S \& von Eckardstein A 2002 Relation of serum levels of sex hormone binding globulin to coronary heart disease in postmenopausal women. American Journal of Cardiology 90 364-368.

Rodbell NMJ 1964 Metabolism of isolated fat cells. Journal of Biological Chemistry 239 375-380.

Ruderman NB, Saha AK \& Kraegen EW 2003 Minireview: malonyl CoA, AMP-activated protein kinase and adiposity. Endocrinology 144 5166-5171.

Saygili F, Oge A \& Yilmaz C 2005 Hyperinsulinemia and insulin insensitivity in women with nonclassical congenital adrenal hyperplasia due to 21-hydroxylase deficiency: the relationship between serum leptin levels and chronic hyperinsulinemia. Hormone Research 63 270-274.

Simoncini T \& Genazzani AR 2003 Non-genomic actions of sex steroids. European Journal of Endocrinology 148 281-292.

Singh R, Artaza JN, Taylor WE, Braga M, Yuan X, Gonzalez-Cadavid NF \& Bhasin S 2006 Testosterone inhibits adipogenic differentiation in 3T3-L1 cells: nuclear translocation of androgen receptor complex with $\beta$-catenin and T-cell factor 4 may bypass canonical Wnt signaling to down-regulate adipogenic transcription factors. Endocrinology 147 141-154.

Smith PJ, Wise LS, Berkowitz R, Wan C \& Rubin CS 1988 Insulin-like growth factor-1 is an essential regulator of the differentiation of 3T3-L1 adipocytes. Journal of Biological Chemistry 263 9402-9408.

Smith U, Axelsen M, Carvalho E, Eliasson B, Jansson PA \& Wesslau C 1999 Insulin signalling and action in fat cells: associations with insulin resistance and type 2 diabetes. Annals of the New York Academy of Sciences 892 119-126.

Speiser PW, Serrat J, New MI \& Gertner JM 1992 Insulin insensitivity in adrenal hyperplasia due to nonclassic steroid 21-hydroxylase deficiency. Journal of Clinical Endocrinology and Metabolism 75 1421-1424.

Stolic M, Russell A, Hutley L, Fielding G, Hay J, MacDonald G, Whitehead J \& Prins J 2002 Glucose uptake and insulin action in human adipose tissue influence of BMI, anatomical depot and body fat distribution. International Journal of Obesity 26 17-23.

White MF \& Yenush L 1998 The IRS-signaling system: a network of docking proteins that mediate insulin and cytokine action. Current Topics in Microbiology and Immunology 228 179-208.

Yang Q, Graham TE, Mody N, Preitner F, Peroni OD, Zabolotny JM, Kotani K, Quadro L \& Kahn BB 2005 Serum retinol binding protein 4 contributes to insulin resistance in obesity and type 2 diabetes. Nature 436 356-362.

Received in final form 31 October 2006

Accepted 27 November 2006

Made available online as an Accepted Preprint

27 December 2006 